\title{
Factors Influencing the Prospect of Asexual Reproduction in Holothuria Arenicola (Semper, 1868)
}

\author{
Moussa RM1*, Abdel Razek F1, Abdel-Rahman SH¹, Mona MH$^{2}$ and \\ Mabrouk El-Gamal M² \\ ${ }^{1}$ National Institute of oceanography and fisheries, Alexandria, Egypt \\ ${ }^{2}$ Faculty of science, Tanta University, Egypt
}

Research Article

Volume 2 Issue 4

Received Date: April 23, 2018

Published Date: June 05, 2018

*Corresponding author: Ragia Moussa Moussa, National Institute of oceanography and fisheries, Alexandria, Egypt, Tel: +2 01120020 346, Fax. +2 03480 1174; Email: ragiamoussa@yahoo.com.au

\begin{abstract}
Asexual reproduction by transverse fission was studied in populations of Holothuria arenicola through investigation of different factors affecting the fission and survival rates. Size, fission position, and temperature impacts were experimentally assessed. It was observed that higher fission rate was recorded in small specimens as compared to large ones. The fission position at 30\% yielded higher fission rate (90\%) as compared to that obtained in $45 \%$ fission (70\%). Temperature showed a considerable effect on either fission or survival rate with a direct proportional relationship between temperature and both rates. At $20^{\circ} \mathrm{C}$, fission started in the $2^{\text {nd }}$ day to be at rate of $20 \%$ which was gradually increased until reaching $100 \%$ by the $8^{\text {th }}$ day; sharp decline of survival rate was occurred reaching $35 \%$ by the $9^{\text {th }}$ day. At $25^{\circ} \mathrm{C}$, fission reached $70 \%$ by the $8^{\text {th }}$ day; the survival rate became constant at $50 \%$ from the $17^{\text {th }}$ day onward. At $30^{\circ} \mathrm{C}$, the highest fission rate was attained in the $4^{\text {th }}$ day but the survival rate was zero in the $5^{\text {th }}$ day. It was noted that the woundhealing period took longer time at $30^{\circ} \mathrm{C}$ than at $20^{\circ} \mathrm{C}$ and $25^{\circ} \mathrm{C}$. Additionally, changes of anterior parts (A) and posterior parts (P) internal organs were followed weekly over two months after fission induction to detect both of the dissolved structure and regenerated one.
\end{abstract}

Keyword: Holothuria Arenicola; Asexual reproduction; Fission rate; Fission position; Temperature; Regeneration

\section{Introduction}

Populations of sea cucumber are being overfished worldwide. Some studies indicate that sea cucumber populations in overexploited fishing grounds may require as many as 50 years in the absence of fishing pressure to rebuild [1-3]. The rapid decline in sea cucumber populations worldwide to support the beche-de-mer market [4] has led to the start of fishing activities in the Egyptian Red Sea coast in late 1996 and in Egyptian 


\section{International Journal of Oceanography \& Aquaculture}

Mediterranean waters in 2000. Several years later, a severe depletion in sea cucumber stocks took place in many areas. This depletion occurred in populations of all sea cucumber species of different economic values. The loss of critical stocks of sea cucumber is likely to have a significant impact on the ecosystem condition and the adjacent marine environment, as a whole [5]. Therefore, there is an urgent need for developing strategies for managing and enhancing the sea cucumber natural stocks.

Possible approaches to enhance and increase yield of sea cucumber stocks may include induced asexual reproduction through fission [2]. Inducing fission in order to double individual numbers would be a promising alternative for holothurian re-population, as suggested by Lokani, et al. [6]. In addition to doubling of a sea cucumber stock, its advantages are: inducement can be done on any number of individuals; survival rates can be very high, as the produced individuals are already adapted to the habitat and begin growing from a relatively large size; threats (predation, etc.), which normally occur during the larval and juvenile stages, are reduced; and costs and technology are low [7].

The most important and abundant holothurian sea cucumber species in Egyptian Mediterranean coast is Holothuria Arenicola [8]. Researches on H. arenicola are scarce worldwide, Mosher [9] studied its distribution in the Bahamas with observations on habitat, behavior, and feeding activity, Tahera and Tirmizi [10] recorded in Pakistan, Iran [11]. Also, the chemical composition of $H$. arenicola was studied [12]. In Egypt, few published studies are available on $H$. arenicola distribution [8]; asexual reproduction [13,14], extraction of bioactive material [15], and captive spawning [16].

The present work aims to study the factors affecting the asexual reproduction yield of $H$. arenicola to provide the optimum conditions needed for attaining the best fission and survival rates.

\section{Materials and Methods}

The collected specimens were maintained in fiberglass tanks (300L) with a thin layer of fine sand on the bottom. The tanks were aerated with an air-blower. Water salinity was $39 \mathrm{ppt}$. The ambient temperature was $26 \pm 1^{\circ} \mathrm{C}$. Water in tanks was changed once daily. Specimens allowed being adapted for one week before conducting experiments.
Prior to fission inducement, samples were anaesthetized in a magnesium chloride $(2.5 \%)$ solution, and then total length (TL) and total weight (TW) were measured for each sample. Asexual reproduction was induced through tightening up the animal's body with rubber bands. The rubber was placed tightly around each animal. Rubber bands were frequently checked and replaced since specimens sometimes managed to rid themselves of rubber bands. Constricted samples were reared in small glass tank filled with fresh, filtered and slowly aerated seawater. Water was fully changed twice each day. No food was added.

The number of divided, undivided and dead samples was reported daily. The percentages of fission and survival rates were calculated for each size group.

$$
\text { Fission Rate }=\mathrm{N} / \mathrm{T} \times 100
$$

Where,

$\mathrm{N}$ = number of divided specimens

$\mathrm{T}=$ total number of specimens

Survival rate was calculated as reported by Reichenbach and Hollway [17] as follow:

$$
\text { Survival Rate }=[(\mathrm{A}+\mathrm{P}) / 2 \mathrm{~T}] \times 100
$$

Where,

$\mathrm{A}+\mathrm{P}=$ number of the anterior parts $(\mathrm{A})$ and posterior parts $(\mathrm{P})$

$\mathrm{T}=$ total number of specimens that had undergone fission

\section{Study of Size Effect}

The experiment was investigated to assess the effect of animal size on fission and survival rates. Specimens were separated into two size groups, each group was held in separate tank. The first group (small size) was ranged from $8.6 \mathrm{~cm}$ to $10.2 \mathrm{~cm}$ TL and from 17.56 to $45.27 \mathrm{~g}$ TW. The second group (large size) was in range of 11.9$15.1 \mathrm{~cm}$ TL and range of 39.96 to $74.42 \mathrm{~g}$ TW. Experiment was conducted in winter and summer. Samples were fitted with rubber bands at $45 \%$ of body length (from anterior end). Temperature was kept at $26 \pm 1{ }^{\circ} \mathrm{C}$. The experiment lasted for 30 days.

\section{Study of Fission Position Effect}

The effect of fission position on fission efficiency and survival rate was determined at two levels. 


\section{International Journal of Oceanography \& Aquaculture}

Samples at range of 9.4 to $12.3 \mathrm{~cm}$ TL and 51.3 to $53.44 \mathrm{~g}$ TW were fitted at $45 \%$ of the total body length (from anterior end) with rubber bands. Samples ranged from 8.2 to $10.8 \mathrm{~cm}$ TL and 31.26 to $43.62 \mathrm{~g} \mathrm{TW}$, were induced to asexual reproduction at $30 \%$ of total length (from anterior end). Both of fission and survival rates were determined over 30 days.

\section{Study of Temperature Effect}

The environmental conditions affecting the fission and survival rate were studied in terms of temperature effect in summer. Twenty specimens were placed in 20, 25 and $30^{\circ} \mathrm{C}$ for 2 days prior to fission inducement. Twenty samples at $20^{\circ} \mathrm{C}$ were at range of 10.2 to $14.7 \mathrm{~cm}$ TL and range of 36.65 to $69.11 \mathrm{~g}$ TW. The sample group at $25^{\circ} \mathrm{C}$ ranged from 11.9 to $15.1 \mathrm{~cm}$ TL and from 39.96 to $74.42 \mathrm{~g}$ TW. The range of samples at $30^{\circ} \mathrm{C}$ was 9.4 to $15.3 \mathrm{~cm} \mathrm{TL}$ and 26.78 to $66.96 \mathrm{~g}$ TW.

$30^{\circ} \mathrm{C}$ was achieved by using the aquarium thermostat heaters, while $20^{\circ} \mathrm{C}$ and $25^{\circ} \mathrm{C}$ were achieved by conducting the experiment in air conditioned room. Samples were fitted with rubber bands at $45 \%$ of body length (from anterior end). The experiment lasted for 30 days.

\section{Study the Difference in Anatomy before and after Fission Induction}

To investigate the fission effect on the internal organs, dissection was performed in normal specimens and divided parts (anterior and posterior parts) resulted from fission induction. Both of anterior and posterior parts were noted over two months to determine the time of anus and mouth formation in anterior and posterior parts, respectively. TL and TW were measured weekly for anterior and posterior parts. Weekly dissection was done for specimens of anterior and posterior parts to follow the organ absorption and regeneration.

\section{Results}

\section{Study of Size Effect}

The size was noted to have an effect on fission and survival rates. Fission and survival rate were significantly different between small and large size samples $(P<0.05)$. Higher fission rate was recorded in small specimens as compared to large ones. The survival rate in small specimens (8.6-10.2 cm TL and $17.56-45.27 \mathrm{~g}$ TW) was ranged from 42 to $75 \%$ (Figure 1). Lower range of survival rate was noted in large specimens $(11.9-15.1 \mathrm{~cm}$ TL and 39.96 - 74.42g TW) to be from 25 to $54 \%$.

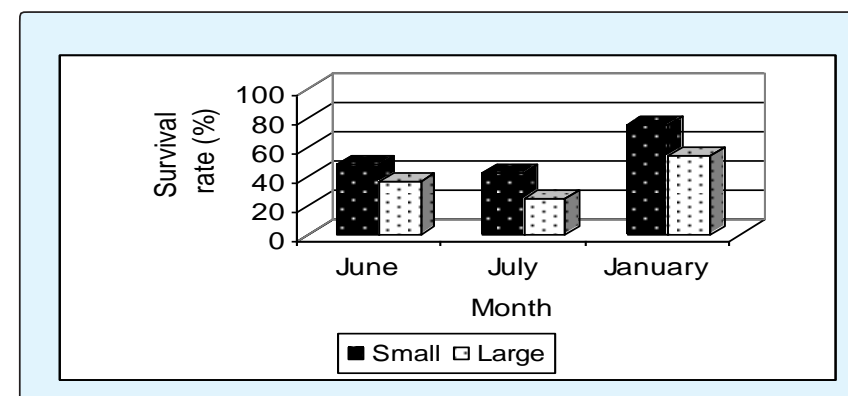

Figure 2: Effect of size on survival rate (\%) of Holothuria arenicola divided parts resulted from fission induction.

Regardless of specimen size, the highest fission and survival rate were obtained in winter (January) while the lowest were in summer (June and July). The wound healing period was ranged from day to two days in both of small and large sized specimens. Fission lasted for 6 days (after fission induction) in summer while it took only 4 days in winter (Figure 2).

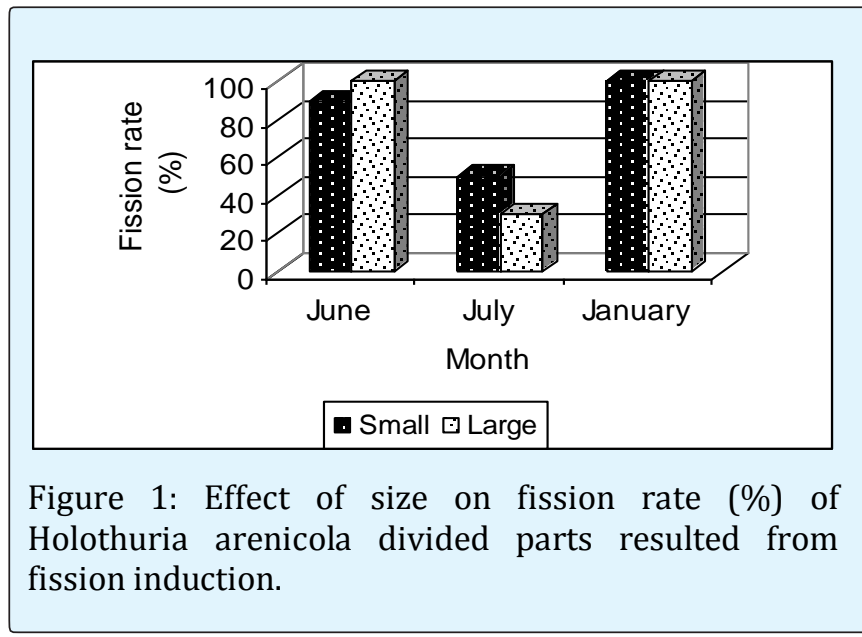

\section{Study of Fission Position Effect}

Fission position was noted to have a considerable effect on both of fission and survival rates. There was a significant difference in fission and survival rates between $30 \%$ and $45 \%$ fission position $(P<0.05)$. The fission position at $30 \%$ yielded higher fission rate $(90 \%)$ as compared to $70 \%$ fission rate obtained in $45 \%$ fission. The fission duration was five days in both specimens fissioned at $30 \%$ and $45 \%$ fission position (Table 1). The survival rate of divided parts resulted from fission at 30\% and $45 \%$ fission position was $81 \%$ and $50 \%$, respectively. The survival rate of anterior and posterior parts was $61 \%$ for each by the end of experiment. 


\section{International Journal of Oceanography \& Aquaculture}

\begin{tabular}{|c|c|c|c|c|c|c|c|}
\hline Month & \multicolumn{2}{|c|}{ Studied Parameter } & Av.TL (cm) & Av.TW(g) & Fission Duration (days) & Fission (\%) & Survival (\%) \\
\hline January & & & $8.5 \pm 1.5$ & $25.48 \pm 1.63$ & 6 & 100 & 64 \\
\hline \multirow{2}{*}{ April } & \multirow{2}{*}{ Fission position } & $45 \%$ & $10.3 \pm 1.82$ & $48.66 \pm 2.85$ & 5 & 70 & 61 \\
\hline & & $30 \%$ & $9.3 \pm 2.4$ & $39.22 \pm 1.69$ & 5 & 90 & 61 \\
\hline June & & & $11.5 \pm 0.85$ & $50.23 \pm 1.23$ & 6 & 90 & 48 \\
\hline \multirow{2}{*}{ July } & \multirow{2}{*}{ Size } & Small & $9.7 \pm 1.03$ & $32.06 \pm 2.16$ & 6 & 50 & 42 \\
\hline & & Large & $13.3 \pm 1.9$ & $48.3 \pm 1.65$ & 6 & 30 & 25 \\
\hline \multirow{3}{*}{ July } & \multirow{3}{*}{ Temperature } & $20^{\circ} \mathrm{C}$ & $13 \pm 2.3$ & $51.84 \pm 1.89$ & 8 & 100 & 30 \\
\hline & & $25^{\circ} \mathrm{C}$ & $13.3 \pm 1.28$ & $48.3 \pm 1.96$ & 8 & 70 & 50 \\
\hline & & $30^{\circ} \mathrm{C}$ & $12 \pm 1.49$ & $40.7 \pm 1.65$ & 8 & 90 & 0 \\
\hline
\end{tabular}

Table 1: Fission duration, fission rate and survival rate of Holothuria arenicola under different conditions.

\section{Study of Temperature Effect}

Temperature showed a considerable effect on either fission or survival rate. There was a significant difference in fission and survival rate between 20,25 and $30^{\circ} \mathrm{C}(P<$ 0.05). It was observed that as temperature decrease, the fission duration decrease. The survival rate became constant by the $15^{\text {th }}$ and $19^{\text {th }}$ day in 20 and $25^{\circ} \mathrm{C}$, respectively.

At $20^{\circ} \mathrm{C}$, no fission was observed in the $1^{\text {st }}$ day after fission induction. Fission started in the $2^{\text {nd }}$ day to be at rate of $20 \%$ which was gradually increased until reaching $100 \%$ by the $8^{\text {th }}$ day (Figure 3 ). Two or three days were required for complete wound healing. 100\% survival rate was attained until the $5^{\text {th }}$ day after fission induction. Afterward, sharp decline of survival rate was occurred reaching $35 \%$ by the $9^{\text {th }}$ day. Onward, survival rate was remained stable with $30 \%$ until the end of experiment (Figure 4). Most of recorded mortality was for specimens eviscerated from the constricted point.

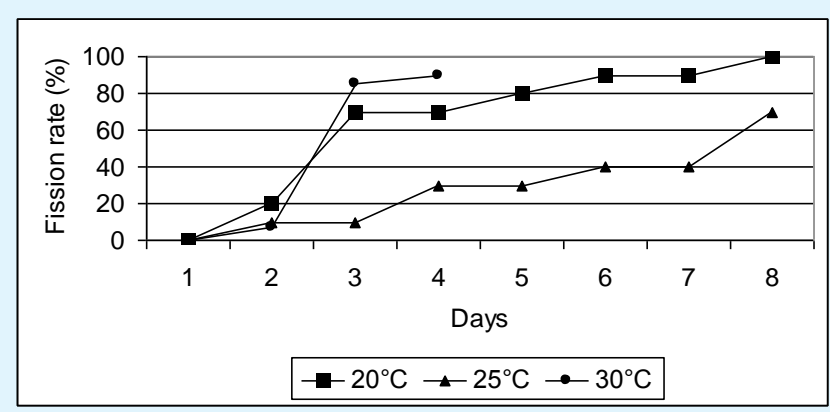

Figure 3: Effect of different temperatures on fission rate of Holothuria arenicola divided parts resulted from fission induction.

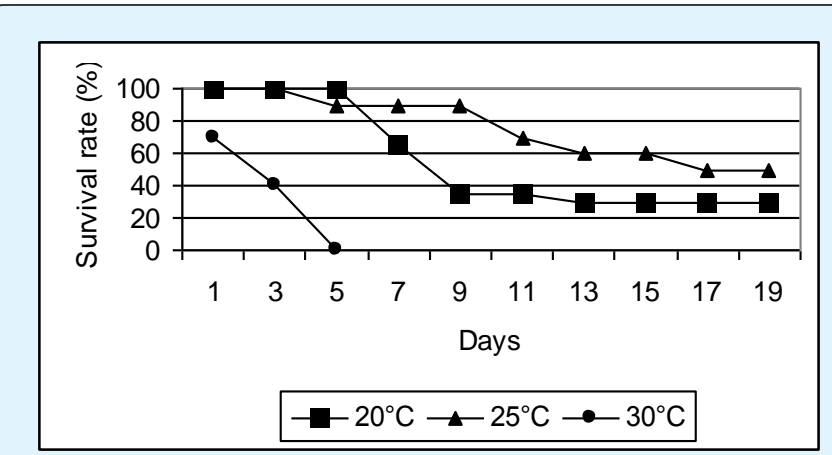

Figure 4: Effect of different temperatures on survival rate of Holothuria arenicola divided parts resulted from fission induction.

At $25^{\circ} \mathrm{C}$, the trend of survival rate was similar to fission rate. Fission was started in the $2^{\text {nd }}$ day to be at rate of $10 \%$ which was gradually increased until reaching $70 \%$ by the $8^{\text {th }}$ day (Figurer 3). The survival became constant at $50 \%$ from the $17^{\text {th }}$ day onward. The wound healing period ranged from 1-2 days.

At $30^{\circ} \mathrm{C}$, the survival rate was sharply declined from $70 \%$ in the $1^{\text {st }}$ day (after fission induction) to zero in the $5^{\text {th }}$ day (Figure 4). Within the four days after fission induction, the highest fission rate was recorded in $30^{\circ} \mathrm{C}$. Most of specimens were eviscerated at the constriction point. Wound healing was observed in few divided specimens which dead by the $5^{\text {th }}$ day. In $30^{\circ} \mathrm{C}$, the woundhealing period took longer time than at $20^{\circ} \mathrm{C}$ and $25^{\circ} \mathrm{C}$.

\section{Study the Difference in Anatomy before and after Fission Induction}

Before Fission Induction: $H$. arenicola with dorsal and ventral views was illustrated in Figure 5. The body is 


\section{International Journal of Oceanography \& Aquaculture}

slender, elongate, and tapered toward both ends. It is brown with contrasting flecks of darker brown and black color. The tegument of $H$. arenicola is thick, smooth and has a tendency to disintegrate rapidly. The weight of the tegument (muscle included) is ranged between 24.94 and $38.96 \mathrm{gm}$, and it is $3 \mathrm{~mm}$ thick. Its mouth is located at the anterior end of its body, and is surrounded by 20 small, yellowish, transparent tentacles. Tentacles (averaging $0.7 \mathrm{~cm}$ in length) are used to collect food. Small, cylindrical tube feet are scattered across the body, but are denser on the lateral margins and the ventral surface. Toward the anterior and posterior ends, the tube feet are found on irregular warts. Two longitudinal rows of 20 dusky blotches often run along the dorsal surface.

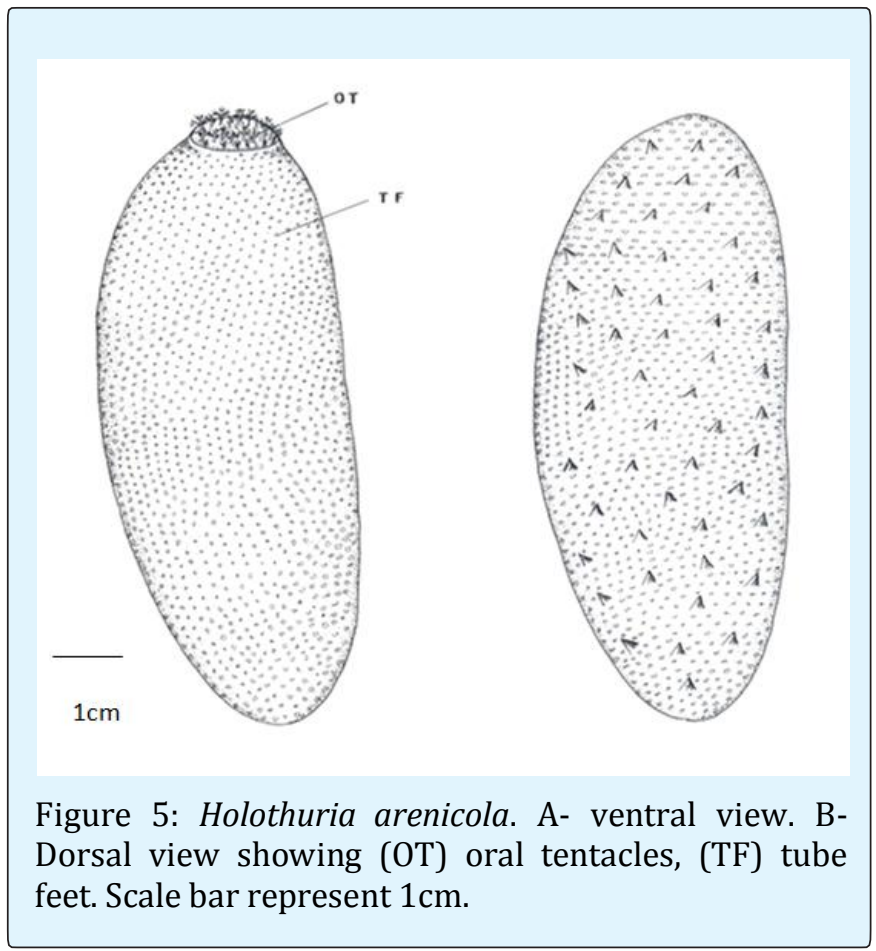

The muscles of normal specimens characterize by five pairs of longitudinal muscular bands that attach from the peripharyngeal calcareous ring up to cloaca. Each muscular band has width ranged from $2-3 \mathrm{~mm}$ and is attached to the tegument in its median part (Figure 6). The average length of the digestive tract is $9.5 \mathrm{~cm}$. The gonads are in the form of one tuft of branched tubules. The gonad weight was in range of $3-7.3 \mathrm{gm}$. The respiratory system is formed from two branched tubes called respiratory trees, on both sides. They opened into cloaca and extend into the coelomic cavity.

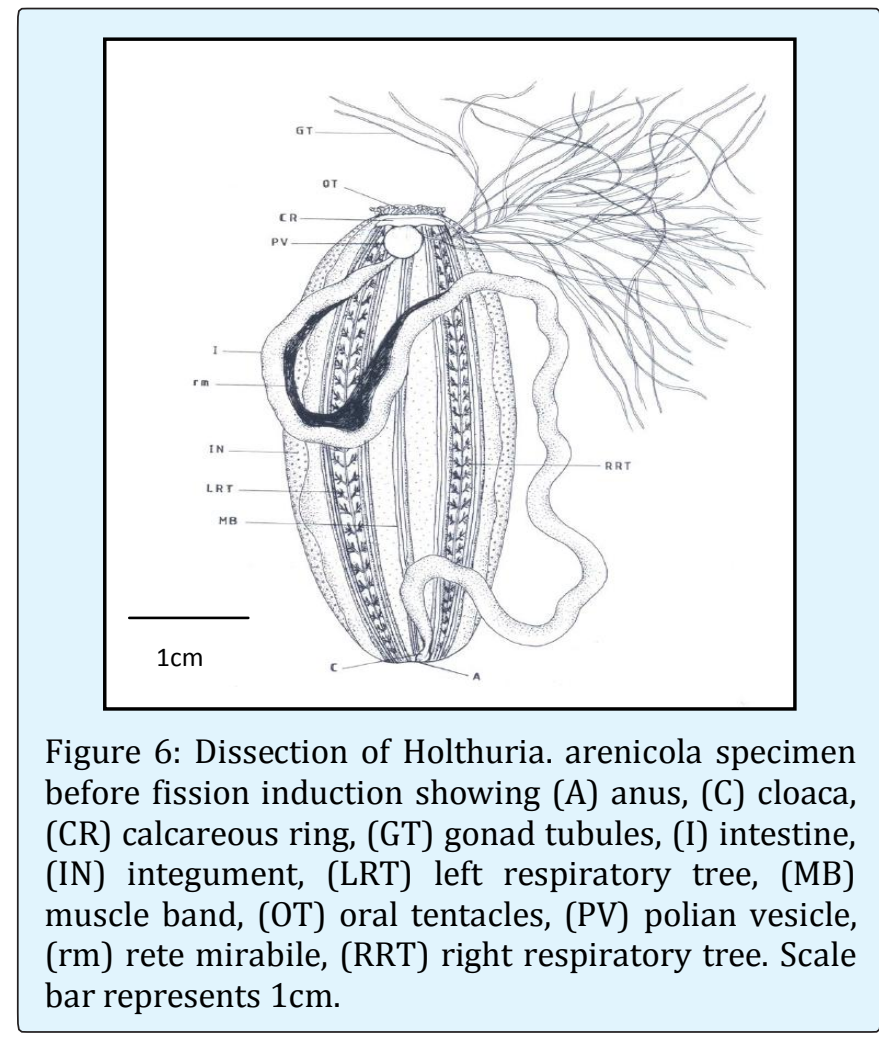

\section{After Fission Induction:}

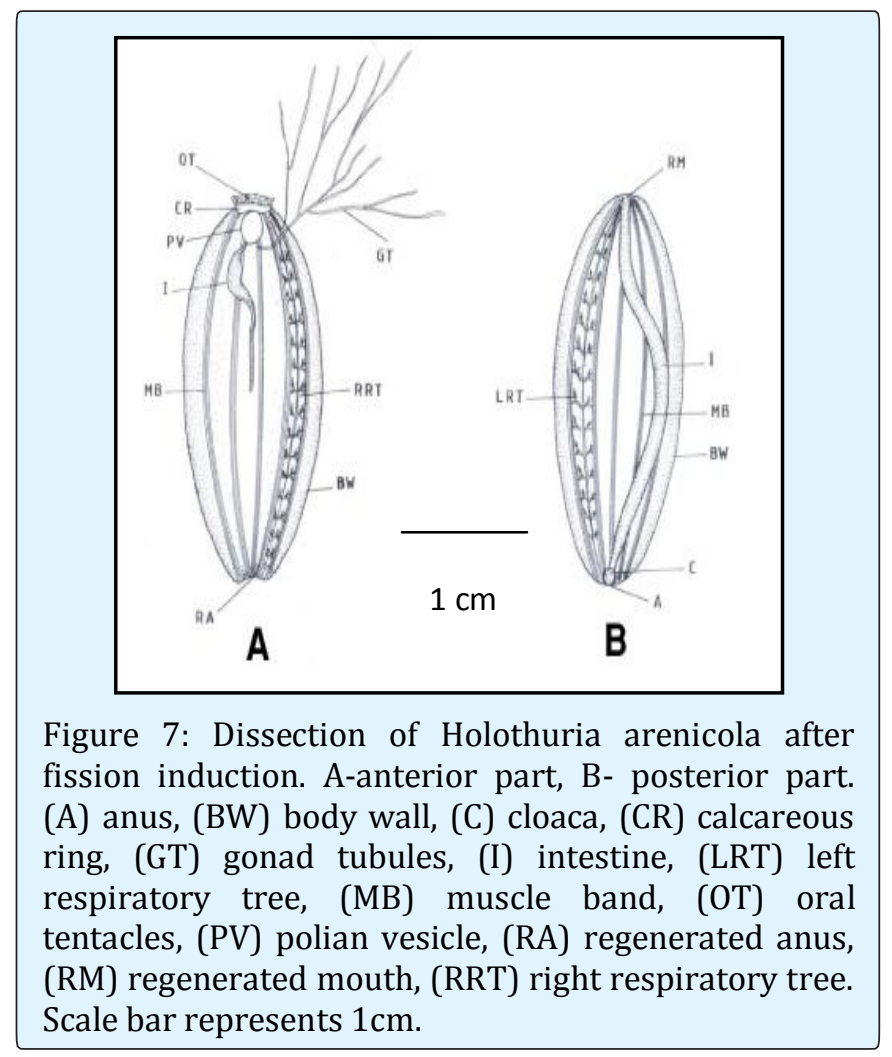




\section{International Journal of Oceanography \& Aquaculture}

I-The anterior part (A)

The anterior part (A) has very few organs. The only ones remaining are the mouth area and its appendages; the gonads (if any); part of the intestine; polian vesicle, and right respiratory tree (Figure 7A).

$\mathrm{B}$-The posterior part $(\mathrm{P})$ : The posterior parts $(\mathrm{p})$ are characterized by presence of the short digestive tract, and left respiratory tree (Figure 7B).

After Two Months after Fission Induction: Changes of internal organs were followed weekly after fission induction through dissection of anterior and posterior parts over two months to detect both of the dissolved structure and regenerated one. The data were summarized in Table 2 over eight weeks.

\begin{tabular}{|c|c|c|c|c|c|c|c|c|c|c|}
\hline \multirow{2}{*}{$\begin{array}{c}\text { Time } \\
\text { after } \\
\text { fission } \\
\text { (Week }\end{array}$} & \multicolumn{5}{|c|}{ Anterior } & \multicolumn{5}{|c|}{ Posterior } \\
\hline & DT & LRT & RRT & $\mathbf{A}$ & S.R (\%) & DT & LRT & RRT & $\mathbf{M}$ & $\begin{array}{l}\text { S.R } \\
(\%)\end{array}$ \\
\hline 2 & $*_{+}$ & - & $*_{+}$ & - & 58 & $*_{+}$ & $*_{+}$ & - & - & 100 \\
\hline 4 & $*_{+}$ & - & $*_{+}$ & - & 58 & - & $*_{+}$ & - & - & 100 \\
\hline 6 & - & - & $*_{+}$ & + & 48 & - & $*_{+}$ & - & + & 60 \\
\hline 8 & - & - & $*_{+}$ & + & 48 & - & $*_{+}$ & - & + & 60 \\
\hline
\end{tabular}

Table 2: Survival rate and changes of internal anatomy of Holothuria arenicola after fission induction over eight weeks.

$\left({ }^{*}\right)$ indicates the remaining structures after fission; $(-)$ indicates that structure are dissolved or not yet regenerated, and (+) indicates that the structure is regenerated; (DT) digestive tract; (LRT) left respiratory tree; (RRT) right respiratory tree; (A) anus and (M) mouth.

A-The anterior part (A): The anterior part (A) dissolves most of the remaining organs (intestine, gonad) after three weeks after fission, and then regenerates them, probably through materials left over after dissolution. The right respiratory tree and polian vesicle are kept from dissolution. The anal area started to regenerate on $28^{\text {th }}$ day after fission.

$\mathrm{B}$-The posterior part $(\mathrm{P})$ : The posterior part regenerates the missing organs (the oral area; gonads; polian vesicle; rete mirabile; digestive tract, and right respiratory tree). It keeps only the left respiratory tree from dissolution. The beginning of mouth area regeneration commenced at the same time of anal area regeneration, on $28^{\text {th }}$ day.

\section{Discussion}

Holothurians are known for their ability to reproduce asexually by fission. Asexual reproduction in sea cucumbers by fission has been studied by several researchers [18-27]. In the present study, H. arenicola was successfully induced to asexual reproduction by using rubber bands as simple effective technique to induce transverse fission. H. arenicola small specimens at range of 8.6-10.2 cm TL and 17.56 - 45.27g TW showed higher survival and fission rate than in large specimens at range of $11.9-15.1 \mathrm{~cm}$ TL and $39.96-74.42 \mathrm{~g}$ TW. In other words, the fission ability increases as the animal size decrease. This finding is in agreement with Uthicke [28] who suggested that the body size of sea cucumber could have an effect on the likelihood of asexual reproduction taking place. Similarly, smaller specimens of Holothuria fuscogilva, H. nobilis, Actinopyga mauritiana, and Stichopus variegatus (both anterior and posterior parts) had higher survivorship and shorter regeneration times relative to adult animals of the same species $[23,25]$ reported that the survival rate of Actinopyga mauritiana of the small size group (average length $12 \mathrm{~cm}$ and average weight 130 g) was $75 \%$, while the survival rate of the large size group (average length $19 \mathrm{~cm}$ and average weight $330 \mathrm{~g}$ ) was $58 \%$.

Regardless of specimen size, both of fission rate and survival rate were observed to be decreased from June to July and attained the highest percentage in January. This finding can be interpreted by the inversely proportional relationship of fission rate and survival rate with ambient temperature. As temperature increased from June to July, there was a decrease in fission rate (36-48\%) and survival rate $(90-100 \%)$ in June to $(25-42 \%)$ and $(30-$ $50 \%$ ) in July, respectively. While as temperature decrease in January, high values were recorded for both of fission $(100 \%)$ and survival rates (54-75\%). Further confirmation for this suggestion achieved by comparing the present results with others obtained previously in study of fission induction of $H$. arenicola in Mediterranean Sea in November [13]. They reported $63.3 \%$ and $63 \%$ survival rate and fission rate, respectively. Moreover, the fission duration was noted to be decreased from 6 days in summer (June and July) to 4 days in winter (January). Similarly, Laximinarayana [26] reported that asexual reproduction in nature is a seasonal event mainly occurring in winter in natural populations. Although the timing differed among different species, fission is a winter phenomenon for all [29]. Therefore, it can be concluded that the efficiency of fission process in H. arenicola and rate of survival of divided parts are temperature related. 


\section{International Journal of Oceanography \& Aquaculture}

Moreover, food availability may influence the occurrence of asexual reproduction. During the cold winter months, bacterial, detritus and diatoms, which some holothuroids feed on, are generally less abundant. Since sea cucumbers cease to feed during the period of regeneration, reduced food availability may be a signal that fission should take place [24].

Concerning fission position, Reichenbach and Holloway [17] induced fission in eight holothurians species. Their results showed a higher survival rate when the rubber bands were placed on the animal's natural fission plane, as in Stichopus chloronotus, the tegument, as well as the width of the muscles and their attachments marked the area being regenerated [30]. In the present study, it was found that the survival rate of anterior and posterior parts after fission at $30 \%$ of total length was significantly higher than that at $45 \%$. Therefore, it is concluded that the position of the split in $H$. arenicola is in $30 \%$ of the total length. Similarly, fission in H. leucospilota occurs at $20-33 \%$ of its body length when measured from the anterior end [31-33]. However, fission occurred at about $52 \%$ of the total length in Stichopus chloronotus, since anterior specimens were slightly larger than posterior ones [30]. The survival rate of posterior parts in $H$. arenicola was significantly higher than that of anterior parts regardless of the studied parameter. This indicates that posterior part has high regenerative ability than anterior one. Likewise, Kilada, et al. [13] reported the survival rate of $H$. arenicola as $90 \%$ and $40 \%$ for posterior and anterior parts, respectively over three weeks. This was similarly reported in $H$. fuscogilva, $H$. nobilis, Actinopyga mauritiana, and Stichopus variegates, since posterior parts had similar or higher survivorship relative to the anterior parts [23]. Further confirmation for the present obtained result was achieved through studying the survival rate of $H$. arenicola over 75 days, none of anterior parts still alive and only $16 \%$ of posterior parts survived. These findings mean that the posterior parts have the ability to regenerate to whole animals, while anterior parts have low or no potential for regeneration. As wise, Reichenbach and Holloway [17] reported that both of Stichopus chloronotus and Actinopyga mauritiana regenerate only the posterior parts into whole animal. Also, Stichopus variegatus was able to regenerate only the posterior part into a whole animal in around 100 days, with $0 \%$ survival of the anterior parts and $80 \%$ survival of the posterior parts [23].

Because of the great critical effect of temperature among other environmental parameters on asexual reproduction, temperature effect was investigated experimentally on the entire fission process. Total mortality in $30^{\circ} \mathrm{C}$ could be considered as sign of the intolerable thermal stress. Also, higher fission rate in 20 , $30^{\circ} \mathrm{C}$ than in $25^{\circ} \mathrm{C}$ may be related to the thermal stress. This interpretation is supported by Uthicke [28] who suggested that stress resulted from unstable habitat, including large fluctuations in water temperature, salinity and food sources may lead to an increase in mortality rates.

There are some conflictions between observations obtained from fission induction in cold month $\left(20^{\circ} \mathrm{C}\right)$ and others recorded from fission induction in low temperature $\left(20^{\circ} \mathrm{C}\right)$. First, the fission duration was four days in January when the ambient temperature around $20^{\circ} \mathrm{C}$, while the fission duration under laboratory controlled temperature $\left(20^{\circ} \mathrm{C}\right)$ was 8 days in the experiment done in June. Second, it was noted that higher fission rate correspond to higher survival rate, while at $20^{\circ} \mathrm{C}$, high fission rate and low survival rate were observed. These two conflictions in addition to high survival rate in January could be attributed to physiological state of animal in which its energy was completely directed toward sexual reproduction during the summer season, not for fission and regeneration. As the spawning season end, gonads resorbed, temperature decreased, and energy redirected to binary fission and regeneration in winter. This hypothesis is supported by the fact that sexual reproduction has metabolic costs. It takes energy to generate and ripen gametes, as well as to release them. In most invertebrates, at least half of the total energy taken in is diverted into gamete production [34]. If the environmental conditions were not favorable for embryonic development, it is best not to waste this energy when nothing may come of it. Hence, it was suggested that high fission at $20^{\circ} \mathrm{C}$ was a result of thermal stress more than being a reaction to similar environmental condition of asexual reproduction period. Moreover, results at $25^{\circ} \mathrm{C}$ were the highest in survival rate with the shortest wound healing period as compared to $20^{\circ} \mathrm{C}$ and $30^{\circ} \mathrm{C}$ because of exerting only fission induction stress under ambient temperature rather doubling stress (fission induction and thermal stress) at $20^{\circ} \mathrm{C}$ and $30^{\circ} \mathrm{C}$.

It is concluded that the optimum conditions for $H$. arenicola high asexual reproduction efficiency are: fission induction in small size specimens in range of 8.6-10.2 cm TL and 17.56 - 45.27g TW; fitting the rubber band at 30\% from the anterior end; conducting the fission induction in winter season or in summer (at $25^{\circ} \mathrm{C}$ laboratory temperature), and start feeding the fissioned parts by the day 94th. Further investigations are necessary to substantiate the current findings together to assess the 


\section{International Journal of Oceanography \& Aquaculture}

fission induction as alternative for $H$. arenicola repopulation.

\section{Acknowledgement}

We are grateful for national institute of oceanography and fisheries (NIOF) in Alexandria, Egypt for financing the project entitled "Aquaculture of sea cucumber and bivalves" which provides us with samples.

\section{References}

1. Battaglene SC, Bell JD (1999) Potential of the tropical Indo-Pacific sea cucumber, Holothuria scabra, for stock enhancement. In: Stock Enhancement and Sea Ranching. Howell BR, Mokness E, Svasand T (Eds.), Proceedings First International Symposium on Stock Enhancement and Sea Ranching, Blackwell Oxford, Pp: 478-490.

2. Bruckner AW, Johnson KA, Field JD (2003) Conservation strategies for sea cucumbers: Can a CITES Appendix II listing promote sustainable international trade?. SPC Beche-de-mer Info Bull 18: 24-33.

3. Skewes T, Dennis D, Burridge C (2006) Survey of Holothuria scabra (sandfish) on Warrior Reef, Torres Strait. CISRO Division of Marine Research.

4. Conand C (2001) Overview of sea cucumbers fisheries over the last decade: What possibilities for a durable management?. Barker M (Eds.), Echinoderms 2000, pp: 339-344.

5. Ahmed MI, Lawrence AJ (2007) The status of commercial sea cucumbers from Egypt's northern Red Sea Coast. SPC Beche de Mer Info Bull 26: 14-18.

6. Lokani P, Polon P, Lary R (1996) Management of beche-de-mer fisheries in the Western Province of Papua New Guinea. SPC Beche-de- mer Info Bull 8: 711.

7. Purwati P, Dwiono SAP (2005) Fission inducement in Indonesian holothurians. SPC Beche-de-mer Info Bull 22: 11-13.

8. Abdel Razek FA, Mona $\mathrm{MH}$, Abdel Rahman SH, El Gamal MM, Moussa RM, et al. (2010) Observation on the abundance of Holothurian species along the Alexandria Coast, Egypt. Rapp Comm int Mer Médit, pp: 39.
9. Mosher C (1980) Distribution of Holothuria arenicola Semper in the Bahamas with observations on habitat, behaviour and feeding activity (Echinodermata: Holothuroidea). Bulletin of Marine Science 30(1): 112.

10. Tahera Q, Tirmizi N M (1995) A new record of Holothuria (Thymiosycis) arenicola Semper, 1868 (Echinodermata: Holothuroidae) from Pakistan. Raffles Bulletin Zoology 43(1): 217-220.

11. Abdul-Rez Dobbagh, Keshavarz M (2011) Three sea cucumbers from the Bandar- e Bostanesh coast (Persian Gulf: Iran). World Applied Science Journal 13 (8): 1933-1937.

12. Salarzadeh AR, Afkhami M, Bastami KD, Ehsanpour M, Khazaali A, et al. (2012) Proximate Composition of Two Sea Cucumber Species Holothuria pavra and Holothuria arenicola in Persian Gulf. Scholars Research Library. Annals of Biological Research 3(3): 1305-1311.

13. Kilada WR, Abdel Razek FA, Yassien, MH (2000) Population growth and asexual reproduction of the sea cucumber Holothuria arenicola from the eastern Mediterranean. Egypt. J Aquat Bull \&Fish 4(4): 119135.

14. Abdel-Razek FA, Abdel-Rahman SH, Mona MH, ElGamal MM, Moussa RM (2007) An observation on the effect of environmental conditions on induced fission of the Mediterranean sand sea cucumber, Holothuria arenicola (Semper, 1868) in Egypt. SPC Beche de Mer Info Bull 26: 33-34.

15. El Nemr A, Abdel Razek FA, El-Sikaily A, Abdel Rahman SH, Moussa RM, et al. (2012) Isolation of Holothurin B from Sea Cucumber Holothurian arenicola collected from Alexandria Coast, Egypt. Blue Biotechnology Journal 1(1): 43-55.

16. Abdel-Razek FA, Abdel-Rahman SH, Moussa RM, Mena MH, El-Gamal MM (2012) Captive spawing of , Holothuria arenicola (Semper, 1868) from Egyptian the Mediterranean coast. Asian J Biol Sci 5(8): 425431.

17. Reichenbach N, Hollway S (1995) Potential for asexual propagation of several commercially important species of tropical sea cucumber (Echinodermata). J Wor Aqua Soci 26(3): 272-278. 


\section{International Journal of Oceanography \& Aquaculture}

18. Emson RH, Wilkie IS (1980) Fission and autotomy in echinoderms. Oceanogr. Mar Biol Annu Rev 18: $367-$ 422.

19. Lawrence JM (1987) A functional biology of echinoderms. Croom Held (Eds.), London, pp: 340.

20. Conand C (1989) The fishery resources of Pacific Island countries. Part 2. Holothurians. FAO Fisheries Technical Paper, pp: 272.

21. Conand C (1993) Reproductive biology of the holothurians from the major communities of the New Caledonian Lagoon. Mar Biol 116(3): 439-450.

22. Conand C (1996) Asexual reproduction by fission in Holothuria atra. Variability of some parameters in populations from the tropical Indo-Pacific. Oceanolology Acta 19(3-4): 209-216.

23. Reichenbach N, Nishar Y, Saeed A (1996) Species and size related in asexual propagation of commercially important species of tropical sea cucumbers. J Wor Aqua Soci 27(4): 475-482.

24. Uthicke S (1997) The seasonality of asexual reproduction in Holothuria (Halodeima) atra, Holothuria (Halodeima) edulis and Stichopus chloronotus (Holothuroidea: Aspidochirotida) on the Great Barrier Reef. Mar Biol 129(3): 435-441.

25. Gaber RH, Ashraf AL, Hanafy $\mathrm{MH}$, Lawrence JA, Ahmed MI, et al. (2004) Mariculture of sea cucumber in the Red Sea the Egyptian experience. FAO Fisheries Technical Paper 463: 373-384.

26. Laxminarayana A (2006) Induced spawning and larval rearing of the sea cucumbers, Bohadschia marmorata and Holothuria atra in Mauritius. Spc Beche de mer info Bull 48-51.

27. Thorne B V, Byrne M (2013) Survivorship of postsplit fission products of Holothuria atra
(Holothuroidea: Aspidochirotida) on the southern Great Barrier Reef. Journal Invertebrate Reproduction \& Development pages 57(4): 293-300.

28. Uthicke S (2001) Influence of asexual reproduction on the structure and dynamics of Holothuria (Halodeima) atra and Stichopus chloronotus populations of the Great Barrier Reef. Mar Freshwater Res 52: 205-215.

29. Lee J, Uthicke S, Byrne M (2006) To split or not to split? Asexual reproduction and population density of aspidochirotid holothuroids at One Tree Island, Great Barrier Reef. Proceeding of $12^{\text {th }}$ International Echinoderm Conference, University of New Hampshire, Durham.

30. Conand C, Armand J, Dijoux N, Garryer J (1998) Fission in a population of Stichopus chloronotus on Reunion Island, Indian Ocean. SPC Beche de Mer Info Bull 10: 15-23.

31. Townsley SJ, Townsley MP (1973) A preliminary investigation of biology and ecology of the holothurians at Fanning Island. Hawaii Institute of Geophysics University of Hawaii, pp: 173-186.

32. Conand C, Morel C, Mussard R (1997) A new study of asexual reproduction in holothurians: Fission in Holothuria leucospilota populations on Reunion Island in the Indian Ocean. SPC Beche de Mer Info Bull 9: 5-11.

33. Purwati P (2004) Fissiparity in Holothuria eucospilota from tropical Darwin waters, northern Australia. SPC Beche-de-mer Info Bull 20: 26-33.

34. Randall D, Burggen W, French D (1997) Eckert Animal Physiology. Freeman WH and company New York, USA. 